\title{
Preliminary study of the influence of red blood cells morphometry on the species determinism of domestic animals
}

\author{
Nezar Adili and Mohamed Melizi \\ Department of Veterinary Medicine, Institute of veterinary sciences and agricultural sciences, \\ University of El-Hadj Lakhdar, Batna -05000, Algeria. \\ Corresponding author: Nezar Adili, email: nezar.adili@yahoo.fr \\ Received: 05-11-2013, Revised: 07-03-2014, Accepted: 10-03-2014, Published online: 08-04-2014
}

doi: 10.14202 /vetworld.2014.219-223

How to cite this article: Adili N and Melizi M (2014) Preliminary study of the influence of red blood cells morphometry on the species determinism of domestic animals, Veterinary World 7(4): 219-223.

\begin{abstract}
Aim: This survey was realized on cattle, sheep, goats, horses, and dogs, in order to study the influence of three morphometric parameters: the diameter, the circumference and the surface of red blood cells on the determinism of these species.

Materials and Methods: For each species, blood samples were taken from 15 adult female by jugular venipuncture with confection of blood smears on microscope slides immediately after blood collection and stained according to the method of May-Gründwald Giemsa. Morphometric study was realized using the software OPTIKA Pro Vision. To better describe the results, the statistical analysis was assessed by using the descriptive Boxplots test, ANOVA, and the Student's t-test.
\end{abstract}

Results: The morphometric parameters of red blood cells are biggest in dogs followed by horses, cattle, and sheep, while goats have the lowest ones.

Conclusion: This investigation allowed us to show that from a drop of blood we can have an idea about the animal species taking into account the diameter, the circumference, and the surface of erythrocytes.

Keywords: circumference, diameter, domestic animals, optika pro vision, red blood cells, surface.

\section{Introduction}

Erythrocytes or red blood cells (RBCs) provide vital functions of oxygen transport, carbon dioxide transport, and buffering of hydrogen ions [1,2]. The typical RBCs shape for multiple veterinary species is the disc or biconcave disc (discoid) resulting in a high surface area to volume ration making the red blood cells deformable. Central pallor can be observed to variable degrees in these species on examination of a peripheral blood smear $[3,4]$. RBCs have no nuclei and no organelles, and thereby no ability to synthesize proteins. The full complement of functional proteins must be present by the time the reticulocyte matures [5].

The mature red blood cell of the adult bovine has a width of 5-6 $\mu \mathrm{m}$, and has minimal central pallor and relatively lifespan of approximately 130-150 days [6, 7]. Anisocytosis is mild to moderate in bovine. Polychromatophils are generally absent from the blood of normal adult cattle [8,9].

Ovine red blood cells are some of the smallest of mammalian RBCs, has a width of 3,2-5 $\mu \mathrm{m}$ and lifespan of 70-150 days $[10,11]$, and do not aggregate or deform as readily as erythrocytes of other species $[12,13]$.

Caprine red blood cells are generally discoid with 2,5-3,9 $4 \mathrm{~m}$ of width and lifespan of 125 days; with an exception in the Angora breed, which frequently have a high percentage of fusiform-shaped RBCs mixed in

Copyright: The authors. This article is an open access article licensed under the terms of the Creative Commons Attribution License (http://creativecommons.org/licenses/by/2.0) which permits unrestricted use, distribution and reproduction in any medium, provided the work is properly cited. with discoid red blood cells $[14,15]$. Polychromasia and reticulocytes are generally absent from the blood of normal adult sheep and goat [13].

The equine red blood cell measure $5-6 \mu \mathrm{m}$ in diameter that has mild to no central pallor, and have a lifespan of 140-155 days. Polychromatophilic RBCs are rarely detected in the peripheral blood of horses because equine reticulocytes mature in the bone marrow even when erythropoiesis is increased $[16,17]$. Rouleaux formation is common in horses because horses have decreased red membrane charge compared to other species. Howell-Jolly bodies can be seen occasionally in equine peripheral blood films in health [17].

The canine erythrocyte measure approximately $7 \mu \mathrm{m}$ in diameter and have a lifespan of 110-115 days [18]. The biconcave shape is more pronounced in the dog than in other domestic animals, giving their red cells a clearly visible central pallor when viewed in the monolayer of well-made blood film [19].

Age [20, 21, 22], sex [23], breed, exercise [24, 25], pregnancy and lactation [26, 27, 28]; emotional state are variables to be considered when establishing references values in domestic animals; altitude polyglobulia (increased RBCs count at high altitude) is well documented and extensively studied [7,29]; while few references were found on red blood cell morphometry.

This study was realized on cattle, sheep, goats, horses and dogs; the purpose is to investigate the influence of morphometric parameters of red blood cells on the determinism of the species, in order to develop criteria selection of domestic animals, taking into account the erythrocytes morphometry. 


\section{Materials and Methods}

Ethical approval: Adequate measures were taken to minimize pain or discomfort in accordance with the International Animal Ethics Committee. The study was approved by the committee framed for the research by the university authority. During the study visits, the researchers introduced themselves and explained the objective and methodology of the study to all animal breeders.

Study area and animals: This study was conducted in the region of Batna, located in the eastern part of Algeria, 410km from the capital city Algiers at an altitude of about $1000 \mathrm{~m}$.

For the realization of sampling we selected 15 non pregnant adult females per species, in order to eliminate the effect of age, sex and pregnancy. All the animals were clinically healthy, free from internal and external parasites, and belonging to the following local breeds: Brown of atlas for cattle, Ouled Djellal in sheep, Arbia for goats, Arab thoroughbred in horses and Sloughi for dogs.

Blood samples and smears: After disinfecting of the sampling area, blood samples were taken from the jugular vein [30]; smears were confectioned on microscope slides just after venipuncture without anticoagulants which may interfere and induce some cytoplasmic and morphometric cell changes and on the extreme provoke degranulation of some blood cells [31, 32, 33]. Slides are precisely identified (order number, species) and classified in slides racks which are equipped with an information sheet including specie and age of the animals following the order number mentioned on the slide; these information are recorded immediately after each sampling and smear realization.

Blood smears staining: Staining of blood smears was carried out following the classical mixed Panoptic staining of Pappenheim, especially by the dye of MayGründwald Giemsa (M.G.G, Romanowsky type) the best and most appropriate staining to mark the mammalians erythrocytes, respecting always the protocol cited by the authors [30,34].

Morphometric study: For several and even until the last years, morphometric studies of red blood cells are essentially based on linear measures of erythrocytes size. Using an ocular micrometer and an objective micrometer is the only valid and recognized method to measure the size of erythrocytes. The diameter of the red blood cells is measured or estimated roughly under an optical microscope at a magnification immersion (x100) [35, 36, 37].

In view of the tedious and the monotonous use of ocular micrometer, other difficulties in non-linear structures measures make the use of the instrument in question disappearing, especially with the exponential technological progress, the advent and the generalization of high performance microscopes.

In our study, we used a high-performance professional optical microscope: OPTIKA B-350 (Ver.4.0.0) ; it is a binocular, modern and ergonomic microscope equipped with a digital camera of high resolution OPTIKAM (Ver.4.1.0) enabling the display of the microscopic image of the smear placed in the microscope on a computer in real time.

The study of morphometric parameters of red blood cells is performed with special OPTIKA ${ }^{\mathrm{TM}}$ (Italy) Pro Vision software of the OPTIKA microscope; measurement operations of this software are the digital version of the more traditional techniques of morphometry with optical microscopes. This is an integral software, which in addition to the functions of image capture and camera control, it allows efficient processing and analysis of microscopic images in an easy manner for any type of application and research.

Before starting the actual morphometric study, it is necessary to scan the microscopic images of red blood cells. The taking of photos for all subjects of different species is an essential step; it allows fixing the microscopic images observed and recording so that we can manipulate them using the software. The information concerning morphometric data of red blood cells is accurate only if a scale has been correctly entered and well calibrated, which requires scanning the micrometer scale engraved on the micrometric slide on the immersion objective (x100).

To study the influence of RBCs morphometry on the determinism of the species of pets, we measured the diameter of red blood cells, which is still estimated in relation to the shape of the cell, and so we developed two new parameters that have not previously treated, which are the circumference and the surface of erythrocytes.

The morphometric study of red blood cells was performed by always respecting the guidelines and instructions of the manufacturer of the software. We measured for each female, the diameter, the circumference and the area of 50 red blood cells, and then we determine the average for all the animal species.

Statistical analysis: To compare the experimental data, a descriptive statistics by boxplots was realized using the Microsoft Office Excel 2010. Analysis of variances (ANOVA) and Student T test, were also performed with the MedCalc statistical software (version 12.7, Copyright (C) 1993-2013 Med Clack software bvba), P value under 0,05 was considered statistically significant.

\section{Results}

The Figure- 1 and Table- 1 shows the influence of the diameter of RBCs on the determinism of the species in domestic animals. We find that the mean of the group of dogs is the highest, followed by that of horses, cattle and sheep respectively; while the average in goats is the lowest; the different boxes do not overlap which suggests significant differences between species. As well as the statistical analysis by ANOVA and Student's T test (comparison of means of different species two by two) confirms the presence of very highly significant 
Table-1. Terminal values, averages, standard deviation and quartiles of the diameter of red blood cells of pets (expressed in $\mu \mathrm{m}$ ).

\begin{tabular}{lccccc}
\hline Species $(\mathbf{n}=\mathbf{1 5})$ & Minimum value & First quartile & Mean and standard deviation & Third quartile & Maximum value \\
\hline Bovines & 4,82 & 4,96 & $5,05 \pm 0,16$ & 5,13 & 5,43 \\
Ovines & 4,23 & 4,50 & $4,55 \pm 0,17$ & 4,67 & 4,86 \\
Goats & 3,09 & 3,37 & $3,40 \pm 0,13$ & 3,50 & 3,60 \\
Horses & 5,15 & 5,43 & $5,59 \pm 0,21$ & 5,76 & 5,82 \\
Dogs & 6,3 & 6,87 & $7,01 \pm 0,30$ & 7,20 & 7,49 \\
\hline
\end{tabular}

Table-2. Terminal values, averages, standard deviation and quartiles of the circumference of red blood cells of pets (expressed in $\mu \mathrm{m}$ ).

\begin{tabular}{lccccc}
\hline Species $(\mathbf{n}=\mathbf{1 5})$ & Minimum value & First quartile & Mean and standard deviation & Third quartile & Maximum value \\
\hline Bovines & 17,81 & 18,55 & $18,95 \pm 0,72$ & 19,35 & 20,25 \\
Ovines & 16,38 & 17,03 & $17,31 \pm 0,53$ & 17,62 & 18,40 \\
Goats & 11,63 & 13,06 & $13,29 \pm 0,65$ & 13,54 & 14,65 \\
Horses & 19,42 & 21,53 & $22,13 \pm 1,19$ & 22,97 & 24,13 \\
Dogs & 20,63 & 25,57 & $25,88 \pm 1,92$ & 26,92 & 28,31 \\
\hline
\end{tabular}

Table-3. Terminal values, averages, standard deviation and quartiles of the surface of red blood cells of pets (expressed in $\mu m^{2}$ ).

\begin{tabular}{lccccc}
\hline Species (n = 15) & Minimum value & First quartile & Mean and standard deviation & Third quartile & Maximum value \\
\hline Bovines & 18,57 & 19,58 & $20,36 \pm 1,34$ & 21,00 & 23,71 \\
Ovines & 15,00 & 16,36 & $17,08 \pm 1,09$ & 17,72 & 19,03 \\
Goats & 7,61 & 9,48 & $9,84 \pm 0,86$ & 10,31 & 11,28 \\
Horses & 21,57 & 26,48 & $27,34 \pm 2,54$ & 29,36 & 30,73 \\
Dogs & 25,55 & 38,23 & $39,56 \pm 5,35$ & 42,63 & 47,05 \\
\hline
\end{tabular}

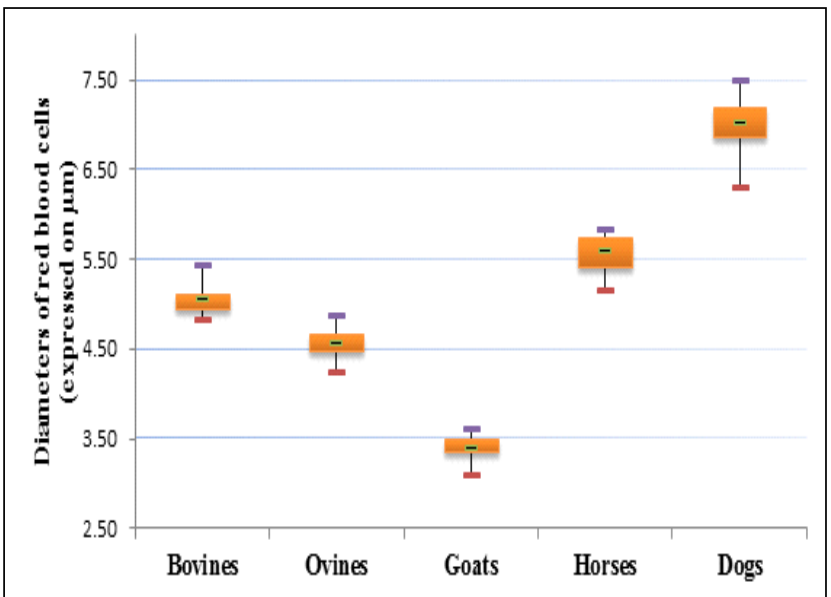

Figure-1. Influence of red blood cells diameter on the determinism of the species of pets.

difference $(\mathrm{p}<0,001)$.

The results presented in the Figure- 2 and in the Table-2, show the influence of the circumference of red blood cells on the determinism of the species of domestic animals; like for the erythrocyte diameter, circumference of red blood cells was also higher in dogs while the lowest value was recorded in goats, the different groups do not overlap ; it should be noted that all the differences are highly significant and at $\mathrm{p}<$ 0,001 (using ANOVA and Student test).

Changes relative to the influence of the surface of red blood cells on the determinism of the species are shown in Figure-3 and also the Table-3; there are differences between species with always an advantage for dogs (no overlap between boxes). Using analytical ANOVA and Student's T test, it turns out that these differences are also very highly statistically significant with always $p<0,001$.

\section{Discussion}

According to our results, it seems that the mor-

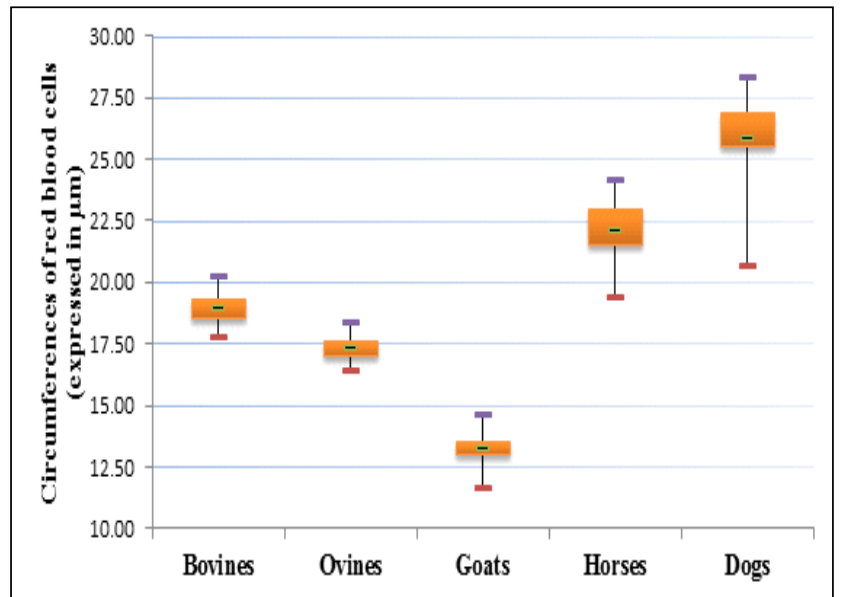

Figure-2. Influence of red blood cells circumference on the determinism of the species of pets.

phometric parameters of red blood cells have an influence on the determinism of the species of domestic animals. For the diameters of erythrocytes, the values obtained in the present study are still within the range of international standards cited by the different authors $[9,13,17,19]$.

Concerning the circumference and the surface of red blood cells, we tried to propose reference values given by intervals (Table-4), since there is practically no studies and publications that provide detailed information on these two parameters.

In addition, we should note that the classical linear and rectilinear measures of the diameter of red blood cells, with the ocular micrometer are quite difficult and imprecise. The measures of circumference and surface using the evoked software are more appropriate for comparative studies especially in front of varying sizes cells. Measures done with this type of software, allowing performing quite correct comparative studies in limiting the human factor involved in the measurements realized with the ocular micrometer 


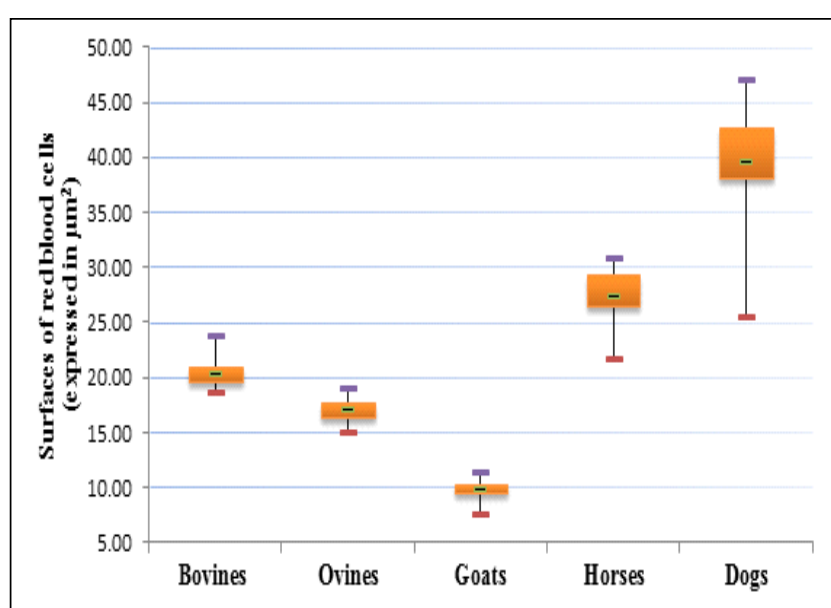

Figure-3. Influence of red blood cells surface on the determinism of the species of pets.

Table-4. Overview of morphometric parameters of pets red blood cells.

\begin{tabular}{|c|c|c|c|}
\hline Species & Diameter (in $\mu \mathrm{m}$ ) & Circumference (in $\mu \mathrm{m}$ ) & Surface (in $\left.\mu \mathrm{m}^{2}\right)$ \\
\hline Bovines & $4,82-5,43$ & $17,81-20,25$ & $18,57-23,71$ \\
\hline Ovines & $4,23-4,86$ & $16,38-18,40$ & $15-19,03$ \\
\hline Goats & $3,09-3,60$ & $11,63-14,65$ & $7,61-11,28$ \\
\hline Horses & $5,15-5,82$ & $19,42-24,13$ & $21,57-30,73$ \\
\hline Dogs & $6,30-7,49$ & $20,63-28,31$ & $25,55-47,05$ \\
\hline
\end{tabular}

by choosing the best place. In addition, this new measurement method is very simple, direct, easy to realize and not expensive.

\section{Conclusion}

This preliminary study on the influence of the diameter, the circumference and the surface of red blood cells on the determinism of the species of domestic animals, realized on 75 blood smears, has shown:

- The morphometric parameters of red blood cells are larger in dogs followed respectively by horses, cattle and sheep, while goats have the lowest parameters.

- $\quad$ For the circumference and the surface of red blood cells, since there were no published standards, we tried to establish and advance reference values for these two parameters. These parameters seem more representative on the research of morphological changes in the size of red blood cells.

- It turns out that the morphometric studies of erythrocytes effectuated by this type of software are more appropriate and more accurate than measurements done with the ocular micrometer.

Finally, through this study we can conclude that from a drop of blood we can have an idea about the animal species, taking into account the morphometric parameters of erythrocytes.

\section{Authors' contributions}

Both authors contributed equally. Both authors read and approved the final manuscript.

\section{Acknowledgements}

The authors would like to thank all staff members in the Department of Veterinary Medicine, Institute of
Veterinary Sciences and Agricultural Sciences, University of El-Hadj Lakhdar (Batna, Algeria), for providing facilities and funds during this research work.

\section{Competing interests}

The authors declare that they have no competing interests.

\section{References}

1. Harvey, J.W. (2008) The erythrocyte: physiology, metabolism, and biochemical disorders. In: Kaneko, J.J., Harvey, J.W. and Bruss, M.L. editors. Clinical Biochemistry of Domestic Animals. $6^{\text {th }}$ edition. San Diego: Acedemic Press. U.S.A. 173-192.

2. Harvey, J.W. (2010) Erythrocyte biochemistry. In: Weiss, D.J. and Wordrop, K.J. editors. Schalm's Veterinary Hematology. $6^{\text {th }}$ Edition. Wiley-Blackwell Publishing Ltd, Ames. U.S.A. Iowa. 131-135.

3. Lording, P.M. (2008) Erythrocytes. Vet. Clin. N. Am. Equine Pract.,, 24: 225-237.

4. Barger, A.M. (2010) Erythrocyte morphology. In: Weiss, D.J. and Wordrop, K.J. editor. Schalm's Veterinary Hematology. $6^{\text {th }}$ Edition. Wiley-Blackwell Publishing Ltd, Ames. U.S.A, Iowa. p144-151.

5. Olver, C.S., Andrews, G.A., Smith, J.E., and Kaneko, J.J. (2010) Erythrocyte structure and function. In: Weiss, D.J. and Wordrop, K.J. editor. Schalm's Veterinary Hematology. $6^{\text {th }}$ Edition. Wiley-Blackwell Publishing Ltd, Ames. U.S.A, Iowa. p123-130.

6. Mohri, M., Sharifi, K. and Eidi, S. (2007) Hematology and serum biochemistry of Holstein dairy calves: age related changes and comparison with blood composition in adults. Res. Vet. Sci., 80: 30-39.

7. George, J.W., Lane, V.M. and Snipes J.N. (2008) Changes in bovine hematology references intervals from 1965 to 2001. Vet. Clin. Pathol., 36: 313-312.

8. Kapale, P.M., Jagtap, D.G., Badukale, D.M. and Sahatpure, S.K. (2008) Haematological constituents of blood of Gaolao cattle. Vet. World, 1(4): 113-114.

9. Wood, D. and Quiroz-Rocha, G.F. (2010) Normal hematology of cattle. In: Weiss, D.J. and Wordrop, K.J. editor. Schalm's Veterinary Hematology. $6^{\text {th }}$ Edition. WileyBlackwell Publishing Ltd, Ames. U.S.A, Iowa. 829-835. 
10. Bórnez, R., Linares, M.B. and Vergara, H. (2009) Haematological, hormonal and biochemical blood parameters in lamb: effect of age and blood sampling time. Livest. Sci., 121:200-206.

11. Šimpraga, M., Šmuc, T., Matanović, K., Radin, L., ShekVugrovečki, A., Ljubičić, I. and Vojta, A. (2013) Reference intervals for organically raised sheep: Effects of breed, location and season on hematological and biochemical parameters. Small Ruminant Res., 112: 1-6.

12. Polizopoulou, Z.S. (2010) Haematological tests in sheep health management. Small Ruminant Res., 92: 88-91.

13. Byers, S.R. and Kramer, J.W. (2010) Normal hematology of sheep and goats. In: Weiss, D.J. and Wordrop, K.J. editor. Schalm's Veterinary Hematology. $6^{\text {th }}$ Edition. WileyBlackwell Publishing Ltd, Ames. U.S.A, Iowa. 836-842.

14. Jain, N.C. and Kono, C.S. (1977) Fusiform erythrocytes resembling sickle cells in Angora goats: light and electron microscope observations. Vet. Sci., 22: 169-180.

15. Mbassa, G.K. and Poulsen, J.S. (1992) The comparative hematology of cross-bred and indigenous east African goats of Tanzania and breeds reared in Denmark. Vet. Res. Commun., 16: 221-229.

16. Piccione, G., Vazzana, I., Giannetto, C., Gianesella, M. and Ferrantelli, V. (2008) Modification of some haematological and haematochemical parameters in horse during long distance rides. Res. J. Vet. Sci., 1(1): 37-43.

17. Grondin, T.M. and Dewitt, S.F. (2010) Normal hematology of the horse and donkey. In: Weiss, D.J. and Wordrop, K.J. editor. Schalm's Veterinary Hematology. $6^{\text {th }}$ Edition. WileyBlackwell Publishing Ltd, Ames. U.S.A, Iowa. 821-828.

18. Khan, S.A., Epstein, J.H., Olival, K.J., Hassan, M.M., Hossain, M.B., Rahman, K.B.M.A., Elahi, M.F., Mamun, M.A., Haider, N., Yasin, G. and Desmond, J. (2011) Hematology and serum chemistry references values of stray dogs in Bangladesh. Open Vet. J., 1: 13-20.

19. Rizzi, T.E., Meinkoth, J.H. and Clinkenbeard, K.D. (2010) Normal hematology of the dog. In: Weiss, D.J. and Wordrop, K.J. editor. Schalm's Veterinary Hematology. $6^{\text {th }}$ Edition. Wiley-Blackwell Publishing Ltd, Ames. U.S.A, Iowa. 799-810.

20. Harvey, J.W., Asquith, R.L., M'nulty, P.K., Kivipelto, J. and Bauer, J.E. (1984) Haematology of the foals up to one year old. Equine Vet. J., 16(4): 347-353.

21. Brun-Hansen, H.E., Kampen, A.H. and Lund, A. (2006) Hematologic values in calves during the first 6 months of life. Vet. Clin. Pathol., 35(2): 182-187.

22. Aoki, T. and Ishii, H. (2012) Hematological and biochemical profiles in peripartum mares and neonatal foals (Heavy Draft horse). J. Equine Vet. Sci., 32: 170-176.

23. Shaikat, A.H., Hassan, M.M., Khan, S.H., Islam, M.N., Hoque, M.A., Bari, M.S. and Hossain, M.E. (2013) Haemato-biochemical profiles of indigenous goats (Capra hircus) at Chittagong, Bangladesh. Vet. World, 6(10): 789793.

24. Aceña, M.C., García-Belenguer, S., Gascón, M. et Purroy, A. (1995) Modifications hématologiques et musculaires pendant la corrida chez le taureau de combat. Rev. Méd. Vét., 146(4): 277-282.

25. Zobra, R., Ardu, M., Niccolini, S., Cubeddu, F., Dimauro, C., Bonelli, P., Dedola, C., Visco, S. and Parpaglia, M.L.P. (2011) Physical, hematological, and biochemical responses to acute intense exercise in polo horses. J. Equine Vet. Sci., 31:542-548.

26. Masoni, F., Lagadic, M., Plassiart, G., Guigand, L. et Wyers, M. (1985) Paramètres hématologiques de la chèvre laitière: Variations physiologiques chez l'animal sain autour de la mise-bas. Rec. Méd. Vét., 161(1): 41-49.

27. Roy, S., Roy, M. and Mishra, S. (2010) Hematological and biochemical profile during gestation period in Sahiwal cows. Vet. World, 3(1): 26-28.

28. Mariella, J., Pirrone, A., Gentilini, F. and Castagnetti, C. (2014) Hematologic and biochemical profiles in standardbred mares during peripartum. Theriogenology, 81(4): 526-534.

29. Kolb, E. (1975) Physiologie des animaux domestiques. Vigot frères édition. France, Paris.

30. Ledieu, D. (2003) : Prélèvemnts en cytologie. Encyclopédie Vétérinaire, Elsevier SAS, Biologie Clinique, 0030.

31. Bacha, W.J.J. and Bacha, L.M. (2000) Color atlas of veterinary. $2^{\text {nd }}$ edition. Lippincott, Williams and Wilkins. U.S.A., Philadelphia. p27-36.

32. Harvey, J.W. (2001) Atlas of veterinary hematology: blood and bone marrow of domestic animals. W.B. Saunders Company. Philadelphia, U.S.A.

33. Denicola, D.B. (2011) Advances in hematology analyzers. Top. Companion Anim. M., 26(2): 52-61.

34. Houwen, B. (2000) Blood film preparation and staining procedures. Lab. Hematol., 6: 1-7.

35. Adams, G.C. (1954) A technique for measurement of erythrocyte diameters. J. Clin. Pathol., 7: 76-78.

36. Tood, J.C. (1979) Clinical diagnosis by laboratory methods. Lippincott, Williams and Wilkins. U.S.A., Philadelphia.

37. Adili, N., Melizi, M. and Bennoune, O. (2013) The influence of age, sex and altitude on the morphometry of red blood cells in bovines. Vet. World, 6(8): 476-478. 